\title{
Ecosystem alterations influenced by the tidal power station on the coast of the Barents sea
}

\author{
par V. X. Semënov \\ Murmansk Marine Btological Institute, Russian Academy of Science
}

\section{I $\square$ THE INSTALLATION OF KISLOGUBS- KAYA}

The basin of experimental Kislogubskaya TPS represents a littlc $(1.1 \mathrm{sq} . \mathrm{km})$ semi-isolated inlet with a narrow strait and underwater silt. In the middle and the upper part of the inlet there are two depressions with a depth of $36 \mathrm{~m}$, separated by the second sill with the depth about $3 \mathrm{~m}$. A rivulet llows into the uppermost part of the inlet. Before the construction of the TPS (in 1964-1968) the water-cxcliange of the Kislaya Inlet with the sea was free, the tides were regular semi-diurnal, the average he:ght of tide was $2.4 \mathrm{~m}$, the monthly alterations range of estronorical tides was from 1.1 to $4.0 \mathrm{~m}$. The basin is holomictic by the type of convection: the winter vertical mixing gets down to the bottom. The common ice conditions were not very hard, as a rule, in winter a solid ice cover was not distributed as far as the imer pat of the inlet with the low salinity of surface water. The wider middle part of the inlet was usually ice-frec. The biota was mostly marinc, brackish-water elements inhabited manly the upermost part. The constant animal population and seaweed of the inlet (regardless of plankton and microbenthos) consisted of about 210-220 species characteristic of inner bights and estuaries of Western Murman.

Kislogubskaya TPS is an installation of double-sided action (working during botil Good and falling tide) with a hydro-aggregate, bottom watcr inlet and surface spillway. The TPS block is installed into the body of groin, dammed is the entrance of inlet. The relative tidal water-exchange with the sea can be controlled within the range of 0 and $50 \%$ (in average per month) of the natural one. lts maximum is up to $60 \%$ during low neap tides. The optimum operational regime provides an average water-exchange about $34-36 \%$. In the regime of idle watcr-Jetting (when the hydroaggregate is turned off) the water-exchange is in average up to $42 \%$, though in spring tides, it is limited by approximately $26 \%$ to prevent the ground washout at the base of TPS block under heavy tidal currents.

As a result of the damming and inflow-outflow regulation of the Kislaya Intet the damaging action of some environmental factors have dramatically increased which earlier had negative efiects on marine components of biota. The freshening increased after long-term decrease of idat waterexchange down to $20 \%$ and lower during impoper two-shif operation of the TPS and hong stoppages when the duct.s are closet due to other reasons. The tiond ice covers pratically all the inlet's area in winter even during the nomal operational regime of the station. The entrance of the Kislaya Inlet had been dammed in 1964-1968 by the filtering embankment. The water-cxchange was literally absent, and the TPS basin was turned into the freshwater-marine basin.

Les altérations de l'écosystème sous l'influence de l'usine marémotrice de la côte de la mer de Barents

Une usine marémotrice fonctionnant dans les deux sens de la marée est en fonctionnement dans le bassin de Kislogubskaya depuis 1968. Au départ on comptait environ 210 à 220 espèces caractèristiques des baies et estuaires de cette région. Mais pendant la constniction du barrage, aqui a durê quatre ans, les échanges d'eau entre l'estuaire et la nèr ont été nuls, puis réduits durant certaines périodes dé l'année (printemps où l'on réditit volontairement les échanges, hiver quand l'eau est en partie prise en glacè L'écosystène a subi les conséquences d'une perte de salinité de l'eau quinze ans après la construction, on a dénombré 115 espèces, avec surtout des pertes dans la żone intercotidale. Après ùne amétioration du fonctionnement de l'usine, le phènomène d'adoucissement de l'eau êtait moindre, ainsi que linfuence de la couche de glace en hiver Certaines espèces sont revenues et on a pratiquement recotwré l'écosystème antérteur. 


\section{THE ECOSYSTEM 15 YEARS LATER}

15 years later the marine ecosystem was restored partinlly, but the vestiges of extensive surface water frestening were evident in sea biotat the absence of Lithothemmion, dead shelts, etc...) down till $3-5 \mathrm{~m}$. The indictions of hydrogen sulphide contanjination of deep waters and muddy bottom scdiments where noted already at 15-20 $\mathrm{m}$ both in the middle and upper parts of the basin. The marine fauna survived at the depths of $3-5$ till about $12 \mathrm{~m}$ mainly in biococtosis of branched Lithothamion.

The significant surtace water treshening and hydrogen sulphide accumulation in summer in decp water took place in early $80 \mathrm{~s}$ during the long-term water cut-off in the ducts and other violations of project operationat regime of TPS Ecological monitoring wias underway after 1983 in the TPS basin. At average values of water-exchange no more than $20 \%$ in stmmer (July) the main pycnocline was the tepth of $12.13 \mathrm{~m}$ in wite middle part anci at $7-8 \mathrm{~m}$ in its narrow inner pert, sepurated by the silf. The period of spring-summer developnent of planktonic conmunity was approximately late for a month, the deviations were noted in the species composition comparable with the outer one. Pyrrophytes predominated in phyloplankton, and the significant increase of representatives of estuarine complex (of genera Evadre, Podon, elc...) were marked in zooplankion; the community was scarce (Rhyzhov's personal communication)

115 species of habitual marine dwellers and seaweed were found out in 1983-1984 (i.e. $53 \%$ ), including i 4 spectes of macroalgae, 96 zoobenthic species and 5 species of fitshes. The intertidal macroatgae (Fucus, Ascophyllum, etc...) were totelly absent. The total species number of invertebrates and plents decreased approximately in 6 times on rocky and stony-boulder intertidal, down tirl 11 species contrary to 6070 ones before the construction of TPS. The benthic biomass decreased by $2-3$ oders. On the tide flats (watten is) the gencral spccies number decreased in 3 times, down till 3 species contraty to $24-25$ ones. The inhabited area of the watten decreased about 4.5 times.

Intertidal benthic communities were at initial succession stage in connection with mussel Mytilus edulis resctting (aiter their die off in Murman in 70s). Matoma balthica predominated by biomass in lower part of the new intertidal, the mussets were sporadic. The brackish-water Chironomus sulfnarius was dominant in the upper part. Arenicola marinat being typical of the watten vanished and has not yet recovered. This species is partially substituted by polychete worm Nereis wrens in the lower par of interidal. The waten and sand beach above approximate mean sea tevel (M.S.L.) were turned into periodically flooded fringe of the coast with compacted sediments and sparse meadow vegelation. Among littoral and upper stblittoral producers remained euryhaline filamentous algac Pylaiella litoralis, Ectocarpus, and diatoms, blue-green algae also, forming felt-shaped dense fouling.

rechnogenic tide transformation entailing long-term exposure of upper and flooding of lower liturat fringes is a disastrously damaging factor influencing littoral biote and its productivity as a whole in the TPS basin. It is caused by itrcgutar watcr-letting of TPS during direct (in falting tide) and reverse (rising ide) turbine working that leads to gradual M.S.L. increase in the basin at least twice a month. Long-term tide component is being generated following monthly tide inequality with a period of about two weeks. The type of tide transformation close to that one and its effects on biota has been described in natural conditions too - in semi-isolated basins with a littoral sill [1]. The tida] inhabited zone shrinks in that case in several times. The most important part of the ecological littoral complexes (Du

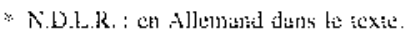

Rietr-Mokiewsky complexes) full out, and pseudolittoral migratory complex, or movable coenocienent (synoccium s.1.) happens to occur.

\section{D AFTER THE IMPROVEMENT OF TPS WORK}

Some positive changes took place after refative improvement of TPS work uccording to the project. The drastic freshening factor had been elminated though the ice-sheet area did not decreased and was not winter severity dependent. Planktonic community did not already difter much from the outer one by its species composition and periods of development, the forms of estuarine complex developeti mainty in the upper part of the inlet. The tittoral zoobenthic communities have begun their gradual formations within new boundaries. Three main species occured on rocks and boulders : Mytilus edulis, Sentbalanus balanoides, Littorina listorea; some other invertebrates happened to occlir at low tide levels. The Mytilus edulis aggregations have almest completely overtapped the sites seuled by Maconat balthica on the lide flats, and also the most part of the former sites dwelled by Chironomus salinarius which had been replaced by marine species (Macma, etc...). Species diversity of polychactes increased significantly, barnacles are extensively distributed on soone embedded area of the watten. Muss development of algat Chorda filtm was noted in upper sublittoral. In some invertebrate species (for instance, Asterias rubens, Strongylocentrowas droebachiensis) flucuations took place followed by outbreaks of poputation abundance.

Thice years after the recovery processes in the ecosystems, the TPS was transferred to be operational in the regime of idle water-letting as the more favorable one for sea biota of its basin. The vertical distribution bourdaries of few mass species on the filtoral zone have stabilized after two-years working of the station in this regime. The successton of bet?thic communities has almost completed on the ticte flat. The number of benthic species there reached 25 , their biomass increased (mainly duc to mussels) up to $2-3.4 \mathrm{~kg}$ per $\mathrm{sq} . \mathrm{m}$ in low littoral zone, and up to $0.1-6.9 \mathrm{~kg} \mathrm{per}$ sc.m in the upper one. The main pycrocline happess at maximum depth of 18 $19 \mathrm{~m}$ in sumner in the wide middle past of the inlet, in the intand upper it usuatly occurs at 7-9 m. The aeration of deep waters have improved in the depression of the intet's mid part, hydrogen sulphide was not more found out amid the bottom waters and sediments; zoobcnthic communities, mainly polychates, recover. The dominant species is Ammotrome anlogaster, the biomass of benthos is up $1620-30 \mathrm{~g}$ per sq.m. The hydrogen sulphide happess to occur in summer deeper than $30 \mathrm{~m}$ in the water and $20 \mathrm{~m}$ in the bottom sediments in the inland upper part only.

The overatl number of macrophyte species reached its iniial number 33. Though Fuctu vesictilostus has become an habitual species in Iower part of the intertidal (beside the imer part of the inict), it is distributed very sparsely ...... the hirhly productive macrophytes belt in the intertidal does rot recover. 11 is caused by itregular fong-term mean sea level fluctuations in the basin, by amplitude comparable with its decreased semi-diumal tides. Only mud- and sand-dwelling species, the forms being tolerant to long-term exposure of capable of movement can survive in the upper part of the new intertidal zone.

\section{REFERENCE}

1ft SeMexoy V.N. - Ecosystim alterations inthuenced by the tidal power plant on the coast of tire Barents Sea. 26 EMBS, 17-21 Sept, :991. Progr. and Abstr. Middedburg, The Nether. lands, 1991. pp. :11-1!3. 